\title{
Accuracy of Clinical Diagnosis of Burst Appendix, a Study of 200 Cases in DMCH.
}

\author{
Md. Rezwan Shah ${ }^{* 1}$, Tasnia Jukhrif Worthy², Mohammed Asraful Alam³, Gursharan Kaur ${ }^{4}$
}

\begin{abstract}
Introduction: Acute appendicitis is the most common surgical emergency. If Simple acute appendicitis progress to perforation, then it is associated with a much higher morbidity and mortality. This study is aimed to evaluate the accuracy of clinical diagnosis of burst appendix. Materials and Methods: This observational study was carried out in the department of surgery, Dhaka Medical College Hospital, Dhaka, from January 2012 to December 2012.Total 200 cases of suspected burst appendicitis were included in this study. Results: Among the 200 cases of suspected burst appendix patients, majority of the cases $48 \%$ were of 25 - 34 years age group, $29.5 \%$ were of $15-24$ years age group, $13 \%$ were of $35-44$ years age group and other age group patients were few in number. Most of the cases $71 \%$ were male and $29 \%$ were female. Higher income group of patients are less sufferer $8 \%$, middle income group and lower income group of patients are more sufferer $59 \%$ and $33 \%$ respectively. Depending on clinical features accuracy of clinical diagnosis of burst appendix is $76.5 \%$. Diagnostic accuracy in male $78.17 \%$ and in female $72.41 \%$.Total patients of confirmatory burst appendix was 153. 111 were male and 42 were female. Male and female ratio was 2.64:1. Diagnostic accuracy $77.9 \%$ in 15-24 years age group, $92.7 \%$ in 25-34 years age group, $50 \%$ in $35-44$ years age group, $35.72 \%$ 45-54 years age group and $0 \%$ in $>54$ years age group of study population. Conclusion: Burst appendix present a challenge to the clinicians because there may be delay in diagnosis, as a result, delay in operation and may develop fatal complications. Surgeons have therefore been inclined to operate when the diagnosis is probable rather than wait until it is certain.
\end{abstract}

Keywords: Burst appendix.

Number of Tables: 04; Number of Figures: 03; Number of References: 22; Number of Correspondence: 04.

*1. Corresponding Author:

Dr. Md. Rezwan Shah

Assistant Professor

Department of Surgery

Z.H. Sikder Women's Medical College \& Hospital, Dhaka.

E-mail: dr.rezwanshah@gmail.com

Mobile Number: 01717-687725

\section{Dr. Tasnia Jukhrif Worthy}

Medical Officer

Department of Surgery

Z.H. Sikder Women's Medical College \& Hospital, Dhaka.

3. Dr. Mohammed Asraful Alam

Registrar

Department of Surgery

Z.H. Sikder Women's Medical College \& Hospital, Dhaka.

\section{Dr. Gursharan Kaur}

Internee

Z.H. Sikder Women's Medical College \& Hospital, Dhaka.

\section{Introduction:}

The appendix is a small, finger-shaped organ in the right lower quadrant of the abdomen. Acute appendicitis is the most common abdominal surgical emergency in the world ${ }^{1}$ which is treated with surgical intervention ${ }^{2}$. It is caused by obstruction of appendix lumen with fecalith, which will lead to bacterial colonization, inflammation, ischemia and progress to perforation ${ }^{3}$.

One of the major reasons for the perforation of the appendix is the delay in diagnosis and treatment of the acute appendicitis ${ }^{2}$. Delay in surgical intervention has been associated with increased rate of perforation from $3 \%$ in patients operated within $24 \mathrm{~h}$ of presentation to $31 \%$ in patients operated at $36 \mathrm{~h}^{4}$. Usually, the perforation may happen after 36 hours of the onset of symptoms but a slight majority of patients with a perforated appendicitis present more than 48 hours after symptom onset ${ }^{5}$. This is a life-threatening condition, as bursting of the appendix can result in spread of the infection in the entire abdomen. So, surgery is indispensable and should be performed without any unnecessary delay ${ }^{6}$. However, appendectomy can be complicated $^{7}$ after the perforation of the appendix, as compared to the surgery which is performed to remove an inflamed appendix which is intact and infected. The mortality rate of non perforated appendicitis is $<1 \%$; however, perforated appendicitis carries a higher mortality rate of around $5 \%{ }^{8}$ Furthermore, postoperative complication rates ranged between 10 and $19 \%$ for uncomplicated acute appendicitis and reaching $30 \%$ in cases of complicated acute appendicitis. 


\section{Materials and Methods:}

This was observational study and carried out in the department of surgery, Dhaka Medical College Hospital, Dhaka, Bangladesh, from January 2012 to December 2012. Total 200 cases of suspected ruptured appendicitis were included in this study. We excluded children under the age of 15 years and Patients operated in the gynaecological department.

Some Operational definition, High income groups: Monthly income of guardian $>20,000$ taka. Middle income groups: Monthly income of guardian 10,000 - 20,000 taka. Low income groups: Monthly income of guardian $<10,000$ taka. Different types of variables evaluated like, Symptoms: Pain in abdomen, Nausea, Vomiting, Fever, Diarrhea, Anorexia, Abdominal distention, Duration of symptoms. Signs: General examination (Dehydration, Temperature, Pulse, BP). Abdominal examination: (Tenderness in RIF, Diffuse tenderness, Rebound tenderness, Pointing sign, Rovsing's sign, Psoas test, RIF muscle rigidity, Abdominal distention, Obliteration of liver dullness, Bowel sounds.) Rectal examination: (Tenderness on right side, Tenderness on recto-vesicl or recto-uterine pouch) Investigations: Laboratory findings, Plain x-ray abdomen, USG of whole abdomen. Operative findings: Site of perforation, Generalized peritonitis, Localized peritonitis, Localized abscess, Periappendiceal fluid collection, Extra luminal appendolith. Early postoperative complications: Fever, Wound infection, Pneumonia, Intra-abdominal abscess, Wound dehiscence Burst abdomen, Prolong paralytic ileus. Confounding variables: Age, Sex, Socioeconomic condition Nutritional status.

Detailed information were obtained in each case. Complete history was taken either from patients or accompanying attendants. Thorough physical examination were done. Relevant investigations and operation notes were collected. All the information was recorded in the fixed protocol. Collected data was classified, edited, coded and entered into the computer for statistical analysis by using SPSS.

\section{Results:}

Age group distribution of the study population, majority of the cases $48 \%$ were of 25 - 34 years age group, $29.5 \%$ were of 15 - 24 years age group, $13 \%$ were of $35-44$ years age group and other age group patients were few in number.

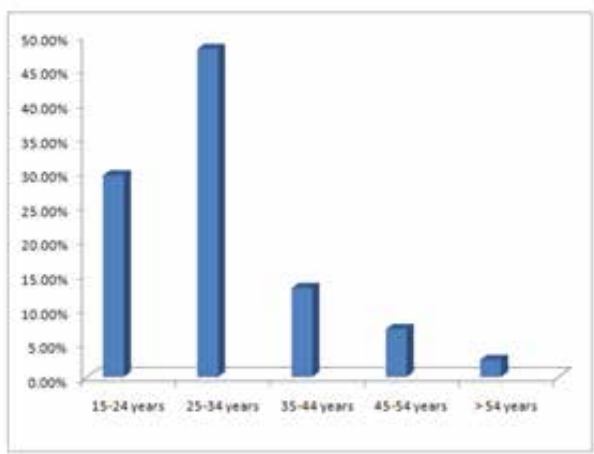

Figure-1: Age distribution of the study population.
Most of the cases $71 \%$ were male and $29 \%$ were female.

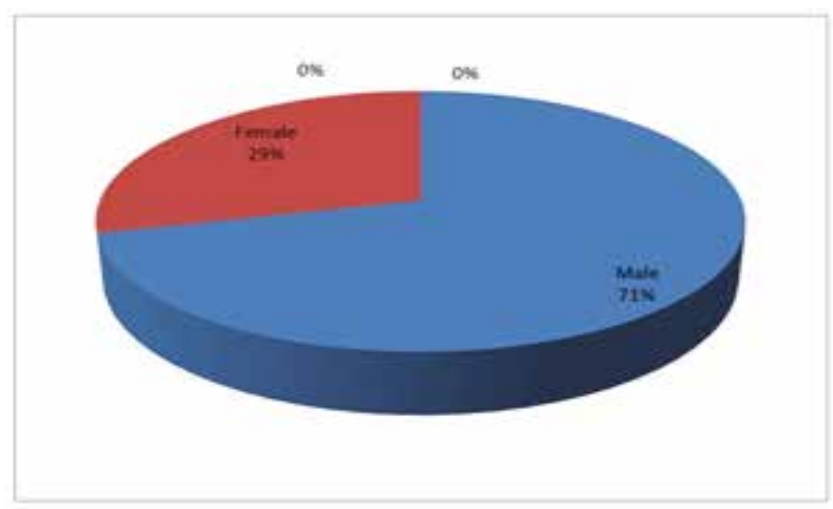

Figure-2: Sex distribution of the patients.

Socioeconomic status of the study population, $8 \%$ were from higher income group, 59\% were from middle income group and $33 \%$ were from lower income group, classification was made from monthly income of guardian.

Table-I: Socioeconomic status of the patients.

\begin{tabular}{lcc}
\hline Status & Numbers & Percentage \\
\hline High income group & 16 & $8 \%$ \\
Medium income group & 118 & $59 \%$ \\
Low income group & 66 & $33 \%$ \\
Total & 200 & $100 \%$ \\
\hline
\end{tabular}

Burst appendix comprises $58.17 \%$ in the age group of $25-34$ years and second peak of $30.06 \%$ in the age group of $15-24$ years.

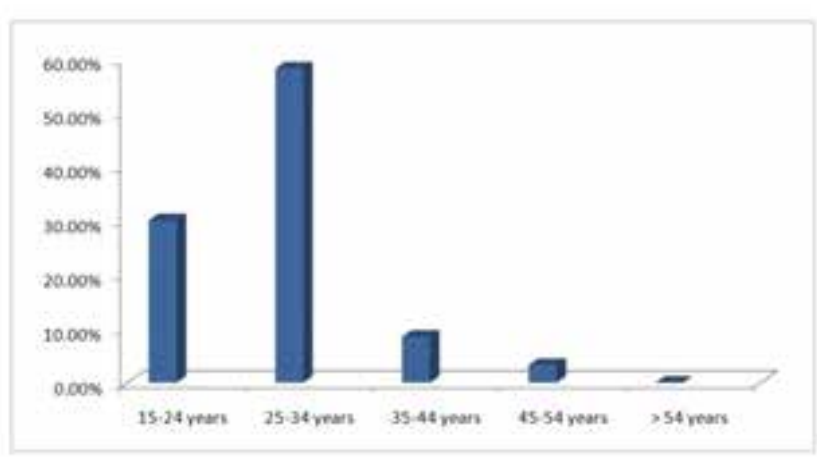

Figure-3: Age incidence of burst appendix.

Depending on clinical features accuracy of clinical diagnosis is $76.5 \%$.

Table-II: Diagnostic accuracy.

\begin{tabular}{lcc}
\hline Diagnosis & Number of Patients & Percentage \\
\hline Correct Diagnosis & 153 & $76.5 \%$ \\
Incorrect Diagnosis & 47 & $23.5 \%$ \\
Total & 200 & $100 \%$ \\
\hline
\end{tabular}

Diagnostic accuracy in male $78.17 \%$ and in female $72.41 \%$. Total patients of confirmatory burst appendix were 153. 111 were male and 42 were female. Male and female ratio was 2.64:1. 
Table-III: Diagnostic accuracy in relation to sex and male-female ratio of burst appendix.

\begin{tabular}{lcccc}
\hline Sex & $\begin{array}{c}\text { Number of } \\
\text { Patients }\end{array}$ & $\begin{array}{c}\text { Correct of } \\
\text { Diagnosis }\end{array}$ & Percentage & $\begin{array}{c}\text { Male and Female } \\
\text { of burst appendix }\end{array}$ \\
\hline Male & 142 & 111 & $78.17 \%$ & $2.64: 1$ \\
Female & 58 & 42 & $72.41 \%$ & \\
\hline Total & 200 & 153 & & \\
\hline
\end{tabular}

Diagnostic accuracy $77.9 \%$ in $15-24$ years age group, $92.7 \%$ in $25-34$ years age group, $50 \%$ in $35-44$ years age group, $35.72 \% 45-54$ years age group and $0 \%$ in $>54$ years age group of study population.

Table-IV: Diagnostic accuracy in relation to age.

\begin{tabular}{lccc}
\hline $\begin{array}{l}\text { Age of } \\
\text { the Patients }\end{array}$ & $\begin{array}{c}\text { Number of } \\
\text { Patients }\end{array}$ & $\begin{array}{c}\text { Number of } \\
\text { Correct Diagnosis }\end{array}$ & Percentage \\
\hline 15 - 24 years & 59 & 46 & $77.9 \%$ \\
25 - 34 years & 96 & 89 & $92.7 \%$ \\
35 - 44 years & 26 & 13 & $50 \%$ \\
45 - 54 years & 14 & 5 & $35.72 \%$ \\
$>54$ years & 5 & 0 & $0 \%$ \\
\hline Total & 200 & 153 & \\
\hline
\end{tabular}

\section{Discussion:}

Acute appendicitis is the most common abdominal surgical emergency and grievous complication of acute appendicitis is burst appendix. The lifetime risk of acute appendicitis is estimated to be $8.6 \%$ for men and $6.7 \%$ for women ${ }^{9}$. Males are affected one and half more times than female ${ }^{10}$ while definite diagnosis could be done in $70-80 \%$ of patients ${ }^{11}$.The diagnosis of ruptured appendix remains mostly on the basis of clinical manifestation as like acute appendicitis. The problem in making a clinical diagnosis of burst appendix is that in addition to appendicitis, there are other possible surgical and non-surgical causes of lower abdominal pain. The signs and symptoms associated with appendicitis have been found to have sensitivity between 16 and 100 percent and specificity between 36 and 95 percent $^{12}$. Differentiate between a perforated and a non-perforated appendix has been a matter of great debate since both have overlapping presentations. Extremes of ages, increasing duration of symptoms, pyrexia, tenderness outside right lower quadrant pain, leukocyte count, C-Reactive Protein levels, Erythrocyte Sedimentation Rate levels neutrophil to lymphocyte ratio and high bilirubin count were good predictors of perforation according to several studies. Inturn these parameters will provide a useful guide between the conservative or surgical treatment of appendicitis, and early use of antibiotics ${ }^{13,14}$. Over the years several scoring systems have been devised to distinguish between these two entities. Various studies show CRP, neutrophil ratio, serum bilirubin CT scan to be very useful in the early and confident diagnosis of perforated appendicitis ${ }^{15,16}$. However, all these modalities are expensive and mostly unavailable in emergency setups of third world countries. Therefore, the age-old tools of history taking and bedside examination remain extremely useful in picking up cases of perforated appendicitis. In their 2010 guidelines, the American College of Emergency Physicians (ACEP) also recommends the use of clinical signs and symptoms in stratifying patients suspected of acute appendicitis ${ }^{17}$.

In this present series, I have studied only 200 cases of clinically diagnosed ruptured appendicitis and admitted in different surgical units of Dhaka Medical College hospital during the period from January 2012 to December 2012 about one year.

There had been many studies on the same and related subjects in home and abroad with various results. The following pages describe the comparative studies of the present study with other studies done in the century and elsewhere.

Figure 1 shows age group distribution of the study population, majority of the cases $48 \%$ were of $25-34$ years age group, $29.5 \%$ were of 15 - 34 years age group, $13 \%$ were of $35-44$ years age group and other age group patients were few in number.

Figure 2 shows that most of the cases $71 \%$ were male and $29 \%$ were female.

Table I shows socioeconomic status of the study population, $8 \%$ were from higher income group, 59\% were from middle income group and 33\% were from lower income group, classification was made from monthly income of guardian. It is generally believed that the lesser cellulose content of the diet may be related to the incidence of acute appendicitis. Enamul et al ${ }^{18}$ was reported, $72.73 \%$ of patients were from middle income group, $25.55 \%$ of patients were from high income group and $2.22 \%$ of patients were from low income group. In our country, because of urbanization, food habit also changing. They are taking less cellulose content diet. So incidence of acute appendicitis in other way burst appendix is increasing in middle and low income group people.

In table II, Patients suspected burst appendix underwent emergency operation and operative findings revealed burst appendix in 153 patients out of 200 patients. So diagnostic accuracy was $76.5 \%$ and diagnostic error in $23.5 \%$.Our results correlates to Williams RF et al study ${ }^{19}$.Their diagnostic accuracy were $92 \%$.

Table III shows diagnostic accuracy in male $78.17 \%$ and in female $72.41 \%$. Total patients of confirmatory burst appendix was 153 . 111 were male and 42 were female. Male and female ratio was 2.64:1. Our results are similar to Zambia is $1.6: 1^{20}$. Males are commoner than female. It may be delayed presentation of man due to hiding the symptoms at working place for fear of loss of job.

Table IV and figure 3 shows that diagnostic accuracy $77.9 \%$ in $15-24$ years age group, $92.7 \%$ in $25-34$ years age group, $50 \%$ in 35-44 years age group, 35.72\% 45 - 54 years age group and $0 \%$ in $>54$ years age group of study population. Burst appendix comprises $58.17 \%$ in the age group of 25-34 years and second peak of $30.06 \%$ in the 
age group of 15-24 years. Our results correlate to USA study $^{21}$ and Deneke $\mathrm{A}^{22}$.

\section{Conclusion:}

From the results of the present study it can be concluded that the accuracy of clinical diagnosis of burst appendix is about $76.5 \%$. The role of available emergency investigations in diagnosis of burst appendix is not significant. To ascertain the significance of this results and its role in management of burst appendix patients large and multicenter studies are required. Burst appendix present a challenge to the clinicians because it can delay in diagnosis, result in delay in operation and can develop fatal complications. So we emphasize on careful history taking and physical examination in such cases which will make the difference between life and death.

\section{Conflict of Interest: None.}

\section{Acknowledgement:}

I would like to thanks all doctors and nursing staffs of surgery department of DMCH who participated and making this study possible.

\section{References:}

1. Makama J. Is acute appendicitis still the most common abdominal surgical emergency. Arch Med Surg. 2017;2:1-2.

https://doi.org/10.4103/archms.archms_40_17

2. Hamza Shirah B, Assad Shirah H, Awad Alhaidari W. "Perforated appendix-delay in presentation rather than delay in the surgical intervention: Retrospective Database Analysis of 2573 Saudi Arabian Patients in 10 Years." Int JSci Study. 2016;4(1):32-36.

3. Sgourakis G. "Are acute exacerbations of chronic inflammatory appendicitis triggered by coprostasis and/or coproliths?" World J Gastroenterol. 2008; 14 (20):3179 -3182 .

https://doi.org/10.3748/wjg.14.3179

PMid:18506922 PMCid:PMC2712849

4. Koyuncu A, Yavuz A, Bulus H, Dogan M. Association between delay in surgical treatment and perforation in acute appendicitis. J Surg Oper Care. 2016;1:205.

https://doi.org/10.15744/2455-7617.1.205

5. Avanesov M, Wiese NJ, Karul M, Guerreiro H, Keller $\mathrm{S}$, Busch P, et al. Diagnostic prediction of complicated appendicitis by combined clinical and radiological appendicitis severity index (APSI). European radiology. 2018;28 (9): 3601-3610.

https://doi.org/10.1007/s00330-018-5339-9

PMid:29541911

6. Hassan MS. Ultrasonography for suspected acute appendicitis. TQMJ. 2010; 4(3): 1-10.

7. Dandapat MC, Panda C. A Perforated appendix: Should we drain? J. Indian Med Assoc. 1992; 90(6):147-8.
8. Wong CS, Naqvi SA. Appendicular perforation at the base of the caecum, a rare operative challenge in acute appendicitis, a literature review. World J Emerg Surg. 2011;6:36.

https://doi.org/10.1186/1749-7922-6-36

PMid:22053953 PMCid:PMC3253676

9. H.H., Ying, C. H., Chi, W. Acute appendicitis or not: Facts and suggestions to reduce valueless surgery, J. Acute Med.2013; 3(4): 142-147.

https://doi.org/10.1016/j.jacme.2013.10.003

10. Humes, D. J. \& Simpson, J. Acute appendicitis. BMJ.2006; 333(7567): 530-534.

https://doi.org/10.1136/bmj.38940.664363.AE

PMid:16960208 PMCid:PMC1562475

11. Hatipoglu, S., Hatipoglu, F. \& Abdullayev, R. Acute right lower abdominal pain in women of reproductive age: Clinical clues. World J. Gastroenterol.2014;14: 4043-4049.

https://doi.org/10.3748/wjg.v20.i14.4043

PMid:24744594 PMCid:PMC3983461

12. Wagner MJ, Mckinney PW, Carprnter LJ. Does this patient have appendicitis? JAMA. 1996 Nov 20;276: 1589-94.

https://doi.org/10.1001/jama.276.19.1589

PMid:8918857

13. Bröker ME1, Van Lieshout EM, Van der Elst M, Stassen LP, Schepers T. Discriminating between simple and perforated appendicitis. JSurg Res. 2012 Jul;176(1):79-83.

https://doi.org/10.1016/j.jss.2011.09.049

PMid:22113128

14. Sevinç MM1, Kınacı E2, Çakar E2, Bayrak S2, Ozakay A2, Aren A2, et al. Diagnostic value of basic laboratory parameters for simple and perforated acute appendicitis: an analysis of 3392 casesUlus TravmaAcilCerrahiDerg. 2016 Mar;22(2):155-62.

15. Omari AH, Khammash MR, Qasaimeh GR, Shammari AK, Yaseen MKB, Hammori SK. Acute appendicitis in the elderly: risk factors for perforation. World $\mathrm{J}$ EmergSurg WJES. 2014 Jan 15;9(1):6.

https://doi.org/10.1186/1749-7922-9-6

PMid:24428909 PMCid:PMC3896723

16. Panagiotopoulou IG, Parashar D, Lin R, Antonowicz $\mathrm{S}$, Wells A, Bajwa F, et al. The diagnostic value of white cell count, C-reactive protein and bilirubin in acute appendicitis and its complications. Ann R CollSurg Engl. 2013 Apr 1;95(3):215-21.

https://doi.org/10.1308/003588413X13511609957371

PMid:23827295 PMCid:PMC4165248 
17. Leung Y, Chan CP, Graham CA, Rainer TH. Acute appendicitis in adults: Diagnostic accuracy of emergency doctors in a university hospital in Hong Kong. Emerg Med Australas. 2017;29(1):48-55.

https://doi.org/10.1111/1742-6723.12738

PMid:28147464

18. Kabir E. Acute appendicitis: Correlation between clinical, preoperative and histopathological diagnosis. A postoperative study of 90 cases. (Dissertation) IPGM\&R,Dhaka; Bangladesh College of Physician and Surgeon, 1996.

19. Williams RF, Blakely ML, Eischer PE, Streck CJ, Dassinger MS, Gupta H, et al. Diagnising ruptured appindecitis preoperatively in pediatric patients. J Am Coll Surg. 2009; 208(5): 819-82. https://doi.org/10.1016/j.jamcollsurg.2009.01.029

PMid:19476843

20. Ehtasam ME. A study on the incidence of appendicectomy in the University Teaching Hospital, Lusaka, Zambia (Dissertation);1998.

21. Addis DG, Shaffer N.The Epidemiology of appendicitis and appendicectomy in United States.American Journal of Epidemiology. 1990; 123(5):916-25.

https://doi.org/10.1093/oxfordjournals.aje.a115734

PMid:2239906

22. Deneke A,Tadesse B. Pattern and clinical presentation of acute appendicitis in adults in Zewditu memorial hospital. Ethiop J Health Sci. 2003; 13(2):117-123. 